\title{
Mounded Mnemonics: Tumuli and Collective Memory in Old Silla*
}

Sebastian Müller**

\section{Introduction}

The monumental and lavishly equipped burial mounds located north of the historical site of Wŏlsŏng Castle in the famous city of Kyŏngju in the southeastern part of the Korean peninsula are among the most prominent archaeological remains of the Silla kingdom (traditionally 57 BCE - 935). Despite being commonly perceived as representative for the kingdom, most of the mounded graves were constructed in a comparatively limited period of Silla's history and in all likelihood at a time when the development of the polity to a centralized kingdom was not yet completed. ${ }^{1}$ Usually, the size, construction, and the equipment of the mounds are analyzed and interpreted as reflections of Silla's social structure, in close alignment to the narratives of the historical records.

Although there is no doubt that the mounded graves represent the elite of the polity (including Silla's rulers), particular aspects of the tumuli

* This work was supported by a research grant of the Busan University of Foreign Studies in 2020.

** Associate (HK) Professor, Institute for Mediterranean Studies, Busan University of Foreign Studies, harleycromag@bufs.ac.kr.

1 Lee Geunjik, "The Development of Royal Tombs in Silla," International Journal of Korean History 14 (August 2009): 93. 
remain underexplored. One of these aspects is the memorial function of the burials for the burying community. In the present article, it is being investigated how the establishment and perpetuation of collective memory with its two main elements 'communicative' and 'cultural memory,' as defined by the German cultural scientist Jan Assmann, may have played a role for the location, size and partly the equipment of the mounds. As will be demonstrated, the analysis of the mounded graves from the perspective of collective memory is a necessary precondition for acquiring a full grasp of the burials' meaning for Silla's society and the process of its formation to a full-fledged state.

First Assmann's concepts of 'communicative' and 'cultural memory' are briefly introduced and set in relation to burials and commemorative practices. This section is followed by a critical appreciation of the historical and archaeological sources of Silla. Afterwards, the manifestation of collective memory in regard to the mounded graves located in the cemetery north of Wŏlsŏng Castle is discussed.

\section{Collective Memory and Burials}

The formation and cohesion of social and political entities rely on a number of elements which might be of different importance for each individual case. One factor that always seems to be of high significance is collective memory. This is because it is the reference to past events, whether true or imaginary, that serves as a source for the assurance and differentiation, in short, of identity construction for a group. ${ }^{2}$ Questions regarding how societies remember and how collective or social memory is stored and transmitted within communities have been discussed by several scholars with varying emphases and differing definitions. ${ }^{3}$ A com-

2 Stefan J. Schustereder, Strategies of Identity Construction. The Writings of Gildas, Aneirin and Bede (Göttingen: Bonn University Press, 2015), 31-34.

3 See e.g. Paul Connerton, How Societies Remember (Cambridge: Cambridge Uni- 
prehensive categorization and analysis of collective memory have been elaborated by the Egyptologist and cultural scientist Jan Assmann. ${ }^{4}$ His research is based on the seminal studies of the French philosopher Maurice Halbwachs, ${ }^{5}$ who was the first to develop a theory on the existence of an external or collective memory that is carried by a group of people. Assmann focusses on an aspect of collective memory that offers, amongst others, a specific understanding for the way knowledge is stored, reproduced and transmitted over an extended period of time. According to Assmann, collective memory is comprised of four elements, which are mimetic memory, the memory of things, the communicative, and cultural memory. ${ }^{6}$ Cultural memory plays a special role in this categorization because it not only exists apart from the former three elements but it also incorporates them. ${ }^{7}$ Although all the types of memory are of importance for understanding collective memory, Assmann refers particularly to the role of the communicative and cultural memory.

According to Assmann, communicative memory refers to events of the

versity Press, 1989) or James V. Wertsch, "Collective Memory," in Memory in Mind and Culture, ed. Pascal Boyer and James V. Wertsch (Cambridge: Cambridge University Press, 2009), 117-137.

4 Jan Assmann, "Kollektives Gedächtnis und kulturelle Identität," in Kultur und Gedächtnis, ed. Jan Assmann and Tonio Hölscher (Frankfurt a. M.: Suhrkamp, 1988), 9-19. Jan Assmann, "Das Kulturelle Gedächtnis," in Kolloquien des MaxWeber-Kollegs XV-XXIII, ed. Wolfgang Schluchter (Erfurt: Max-Weber-Kolleg, 2001), 9-27. Jan Assmann, Cultural Memory and Early Civilization: Writing, Remembrance and Political Imagination (Cambridge: Cambridge University Press, 2011).

5 Maurice Halbwachs, The Collective Memory (New York: Harper and Row Publishers, 1980).

6 Assmann, Cultural Memory, 5-7. Mimetic memory refers to actions which become embodied and usually transmitted through imitation. The memory of things points to the role that objects play in defining people's identity and the objects' reference to different periods in the past.

7 Assmann, Cultural Memory, 6. 
recent past ${ }^{8}$ with varying impact on the community. The content of this memory might include specific knowledge and references to normative values. Nevertheless, there is no formal way this memory is recalled; it is based on daily communication which ultimately shapes memory according to the social environment and group-related norms. ${ }^{9}$ The details of communicative memory might, therefore, change over time due to alterations or the occurrence of new events. Ultimately, the contents of communicative memory will be forgotten if it is not of specific relevance for the community anymore. Research has shown that this happens after eighty to hundred years, or after three to four generations. ${ }^{10}$ Memory that is older than this timeframe belongs in preliterate societies to the realm of cultural memory. The hiatus in collective memory that is located between the events of the communicative and cultural memory is called the 'floating gap. ${ }^{11}$ It is a floating gap because the hundred-year lifetime of communicative memory remains the same for each generation. Cultural memory is characterized by its transcendence from daily life. ${ }^{12}$ It refers to collective key moments, whether historical or mythological, which provide meaning for the group and thus develop the necessary drawing power for keeping the community together. ${ }^{13}$ Recalling cultural memory is not a matter of coincidence or of one's capacity to remember, it rather happens in a regular and well-structured manner. This is also the reason why cultural memory may potentially reach back over hundreds and even thousands of years. The main modes of recalling and re-experiencing content stored in cultural memory are "assembly and personal presence," 14 which is realized through the performance of rites and festivities. ${ }^{15}$ In this

8 Assmann, Cultural Memory, 36.

9 Assmann, "Kollektives Gedächtnis," 10-11.

10 Assmann, "Kollektives Gedächtnis," 11.

11 Assmann, Cultural Memory, 41.

12 Assmann, Cultural Memory, 38.

13 Assmann, Cultural Memory, 38.

14 Assmann, Cultural Memory, 42.

15 Assmann, Cultural Memory, 42. 
context the setting, the role of the participants, and the theme are firmly defined. ${ }^{16}$ The regular occurrence and the observance of the rites by all participants might be also a powerful instance to prevent alterations, although changes and manipulations of cultural memory might be a recurrent issue. Rites and festivals are non-mundane, extraordinary events which provide a setting in which the content of cultural memory is recited and performed, often by specialists such as shamans, bards and druids. ${ }^{17}$ It is the multimedia character of the events, appealing to all of the participants' senses such as special performances, music, dances, feasts and many more that lead to an inscribed or embodied memory that can be automatically recalled in future events. ${ }^{18}$

Cultural memory is of particular significance in pre-literate societies because there is no other method to pass group-related knowledge and core-narratives from generation to generation over a long period of time. ${ }^{19}$ A noteworthy consequence of the need for personal participation in order to recall cultural memory is that the size of pre-literate societies is necessarily limited. ${ }^{20}$

From an archaeological perspective it is impossible to know or reconstruct the content of cultural memory without additional information from written sources or imageries. Since the practices of constructing and recalling cultural memory are, however, reflected in the material culture, it is at least possible to recognize patterns and elements that might help to

16 Assmann, Cultural Memory, 39, 42.

17 Assmann, Cultural Memory, 42.

18 See Filip DeBoeck, "Bodies of Remembrance: Knowledge, Experience and the Growing of Memory in Luunda Ritual Performance," in Rites et Ritualization, ed. Georges Thinès and Luc de Heusch (Paris and Lyon: Librairie Philosophique J. Vrin, 1995), 116, 120.

19 Assmann, Cultural Memory, 8.

20 Ulrich Veit, "Kulturelles Gedächtnis und materielle Kultur in schriftlosen Gesellschaften: Anthropologische Grundlagen und Perspektiven für die Urgeschichtsforschung," in Die Dinge als Zeichen. Kulturelles Wissen und materielle Kultur, ed. Tobias L. Kienlin (Bonn: Rudolf Habelt, 2005), 27. 
understand some basic aspects of cultural memory and how it varied between different groups. Cultural memory needs reference points in space to unfold its meaning for the community in the same way as place is generally important for identity construction. ${ }^{21}$ These reference points may be geographical landmarks or purposefully erected monuments. It is their location in space that is a crucial aspect for enabling the remembrance process. ${ }^{22}$ Assmann refers to landscapes that are filled with natural and human-made mnemonic signs as mnemotopes. ${ }^{23}$ The mnemonic character of the material world can be scaled down from the landscape to the settlement and house, and even further down to the objects that people possess. ${ }^{24}$ Generally, the things that people surround themselves with are producets of their time and a reference to the past or anchors of identity. ${ }^{25}$ As Bjørnar Olsen has emphasized, things impose through their position and shape particular behavior patterns on the people who thereby develop a habit memory. ${ }^{26}$

According to Assmann, "memories of the dead are the primal form of cultural memory." ${ }^{27}$ Funerals and burials provide, thus, an entry to the collective memory of a community. A funeral is an event that will become part of the communicative memory and it is a re-connection to cultural memory through the mortuary rituals. ${ }^{28}$ Obviously, funerals are not events that can be scheduled in advance, in contrast to seasonal festivities. Nevertheless, they are inevitably reoccurring incidents. The death of a member of the community, particularly if the deceased held a high position in the social structure, might be in many aspects a source of social

21 Assmann, Cultural Memory, 25.

22 Assmann, Cultural Memory, 24.

23 Assmann, Cultural Memory, 44.

24 Assmann, Cultural Memory, 24-25.

25 Bjørna Olsen, In Defense of Things. Archaeology and the Ontology of Objects (Lanham: Altamira Press, 2010), 124, 126.

26 Olsen, In Defense of Things, 120.

27 Assmann, Cultural Memory, 45.

28 Assmann, Cultural Memory, 45. 
tension. The recalling of the core narratives that keep the community together is, thus, one possible attempt to restore the order. Although cultural memory is important for the entire community, it is particularly the elite stratum of a society that might have an interest in recalling and controlling it. This is because a crucial aspect for the legitimation of authority is founded in origin or ancestry, ${ }^{29}$ which is part of the information stored in cultural memory. Linking one's own lineage to historical or mythological key moments and figures is, therefore, a powerful means to secure the elevated position of one's group or to justify its claim to power.

Funerals seem to also be events that might offer the best opportunity for altering cultural memory by introducing new or slightly changed narratives which may influence the discourses within the society. The emotional reaction that the death of a high-ranking member of the community may cause, in connection with the above-mentioned sense-stimulating character of the rituals, renders the participants susceptible to manipulations.

The need to minimize the friction that occurs at the death of a leading figure is particularly prevalent in societies with a less firmly set power structure, but even in the case of a clear succession line, measures that signal continuity and order might be necessary. ${ }^{30}$ The gap that is left by an individual who held considerable power within his or her community is inevitably inviting competitors to re-negotiate their position within the power structure and to shape narratives that might be favorable for them. These transition periods are thus particularly dangerous for the leading

29 Sebastian Brather, Ethnische Interpretationen in der frühgeschichtlichen Archäologie. Geschichte, Grundlagen und Alternativen (Berlin/New York: Walter de Gruyter, 2004), 113. Klaus Graf, "Ursprung und Herkommen. Funktionen vormoderner Gründungserzählungen," in Geschichtsbilder und Gründungsmythen, ed. Hans-Joachim Gehrke (Würzburg: Ergon-Verlag, 2001), 23-36.

30 Schwedler, Gerald, Ruth Schilling and Sebastian Kolditz, "D. Gedächtnis, Gedenken und Herrschaft in transkultureller Perspektive," in Monarchische Herrschaftsformen der Vormoderne in transkultureller Perspektive, Wolfram Drews, Antje Flüchter et al. (Berlin/Munich/Boston: De Gruyter), 275. 
group and an opportunity for potential competitors. The latter may see the death of one of their group members as an opportunity to formulate their claim to power through an impressive funeral that contests official cultural memory. The funeral is only one aspect in which cultural memory is recalled but for archaeologists it is the most visible and accessible part, albeit the grave is just the end product of the actual rituals and performances.

\section{Silla - The Historical and Archaeological Sources}

The history of Silla, Paekche and Koguryŏ, which are the eponymous polities of the so-called Three Kingdoms period (traditionally dated between $57 \mathrm{BCE}$ and $668 \mathrm{AD}$ ), are covered by several historical sources of which the Samguk sagi (三國史記, 'History of the Three Kingdoms') and the Samguk yusa (三國遺事, 'Memorabilia of the Three Kingdoms') are the most important. While the Samguk sagi provides a historical account in the form of annals for each ruler of the three kingdoms, the Samguk yusa is a compilation of anecdotes, myths and supernatural events. Due to the seemingly matter-of-fact tradition presented in these sources and due to the absence of equivalent alternatives, modern academic and popular historiography largely follows their description of the three kingdoms. However, the fact that both the Samguk sagi and Samguk yusa were compiled several centuries after the events they report on (1145 and the 1280s respectively) one should exercise caution of their actual validity. Indeed, critical readings have revealed several problems. One of them is the early foundation date of Silla that renders it older than the two other kingdoms whose earlier existence is, however, attested to by Chinese sources. ${ }^{31}$ These as well as other inaccuracies or even misrepresentations are mani-

31 See for instance Jonathan W. Best, A History of the Early Korean Kingdom of Paekche (Cambridge, MA: Harvard University Press, 2006), 8-11. 
fold in historical sources. ${ }^{32}$ The consequence must be a very critical stance towards the reported "facts," although there is no doubt that the written sources contain information that is not derivable from the archaeological record. Nevertheless, instead of interpreting the archaeological finds exclusively from the perspective of the historical sources, which is coming close to a degradation of archaeology to a mere auxiliary science, the archaeological record should be explored beyond the narrow borders defined by the historical tradition.

From the perspective of the archaeological record, Silla is not visible as a cultural entity before the fourth century. ${ }^{33}$ The most distinct indicators are mounded graves with a wooden grave chamber which are embedded in and covered by a massive packing of cobble stones. The deceased was placed in the grave with personal adornment and a number of objects, at times also with other individuals who might have been human sacrifices. The biggest accumulation of these graves is located in the southern part of the modern town of Kyŏngju, where also the old center of the city, Wŏlsŏng castle, is situated. Most of the richly furnished burial mounds in Kyŏngju were constructed during the Maripkan period, a rather short, albeit crucial time in Silla's history (356-514) which is named after the official title that the rulers of the polity were carrying then.

Despite contrary accounts in the written sources, there are reasons to assume that Silla was not a full-fledged kingdom during the Maripkan period, but rather in the process of state formation. ${ }^{34}$ The meaning of the title Maripkan implies the ruler was a primus inter pares and not an uncontested ruler coming from a firmly established succession line. ${ }^{35}$ It

32 See for instance Mark E. Byington, "Some Problems with Early Koguryŏ-Silla Relations Described in the Samguk sagi," Seoul Journal of Korean Studies 29, no. 1 (June 2016): 115-132.

33 Jack Davey, "Unreliable Narratives: Historical and Archaeological Approaches to Early Silla,” Seoul Journal of Korean Studies 29, no. 1 (June 2016): 17.

34 Lee, "The Development of Royal Tombs," 93.

35 Richard D. McBride II, "Introduction," in State and Society in Middle and Late Silla, ed. Richard D. McBride II (Cambridge, MA: Korea Institute, Harvard Uni- 
seems that Silla's development into a centralized kingdom was not completed before the reign of King Pŏphŭng (r. 514-540 AD) and his successor Chinhŭng (r. 540-576). Approximately around this same time the wooden chamber graves with a stone mound were replaced by mounded graves with a stone chamber and a side entrance. ${ }^{36}$ The constant accessibility of these graves allowed for their repeated usage but also for the opportunity to remove older artefacts, which renders these graves less informative. The growing influence of Buddhism, recognized as a state religion by King Chinhŭng, led eventually to a fundamental change of the burial practice as cremation became the predominant way of body treatment. ${ }^{37}$ The ashes of the deceased were usually buried in a covered bowl that is rarely accompanied by a few small vessels. An exception from this norm are the burials of the rulers of the kingdom, who were still interred in mounded graves in different locations in the wider area of Kyŏngju. ${ }^{38}$

\section{The Cemetery North of Wŏlsŏng}

Wŏlsŏng Castle, located at the southern edge of the city center of modern Kyŏngju, is one of the oldest, still visible structures of Silla. The site and its powerful rampart are outlined in a crescent shape next to the Namchŏn River. It is very likely that Wŏlsŏng was the center of Saro, as the polity was called before Chijŭng (r. 500-514 CE) changed its name to Silla. Mounded graves and cemeteries from the entire time of Silla's existence are distributed in closer and wider distance from Wŏlsŏng in the plain and in the mountains that surround the Kyŏngju basin. As mentioned above, the biggest accumulation of mounded graves of the Mar-

versity, 2010), 6.

36 Gina Lee Barnes, "The Emergence and Expansion of Silla from an Archaeological Perspective," Korean Studies 28 (2004): 26.

37 Barnes, "The Emergence and Expansion," 26.

38 Lee, "The Development of Royal Tombs," 102. 
ipkan period is located north of Wŏlsŏng in close range to the fortress. The size of the graves and their equipment suggest that this cemetery was also the place where the highest ranking members of the Silla polity were buried. The area was used as a burial ground before, but it seems that the graves of the Three Kingdoms period do not take the earlier burials into account. $^{39}$

The currently visible distribution of the mounded graves in the cemetery shows remarkable patterns (fig. 1). For instance, most of the bigger and monumental tumuli were placed in the western and northwestern areas. Single graves and smaller burial groups appear to be more or less irregularly scattered across the area, but the majority of mounds seem to be part of larger clusters. Although the distribution and clustering of the tumuli appear to be the result of an organic growth of the cemetery, there are indicators that their location was also determined by the topography. It seems that the constructors of the mounds avoided the vast wetlands north of Wŏlsŏng. ${ }^{40}$

The development of the cemetery north of Wŏlsŏng has been discussed by several authors, who all assume a linear expansion from south to north. ${ }^{41}$ Closely following the information derived from the written sources, some of the bigger mounds are ascribed to the six known rulers of the Maripkan period, which results in a chronological progression in six stages. ${ }^{42}$ Smaller mounds in proximity to the bigger tumuli are more or less arbitrarily grouped together. The graves in the eastern part of the cemetery are usually not discussed in these models at all. The main prob-

39 Yun Hyoungjun, "The Distributional Patterns of Silla Burial Grounds and the Character of Outer Coffin Tombs in Jjoksaem Site, Gyeongju," Munhwajae 50, no. 4 (December 2017): 215.

40 Shim Hyeoncheol. "Kyŏngjubunjiŭi kojihyŏnggwa taerŭngwŏn irwŏnsillagobunŭi ipchi." Munhwajae 51, no. 4 (December 2018): 234-253.

41 See Sebastian Müller, "Monumental Burial Mounds in Kyŏngju: Remarks on their Socio-political Meaning," International Journal of Korean History 24, no. 2 (August 2019): 147, fig. 8.

42 Müller, "Monumental Burial Mounds," fig. 8. 


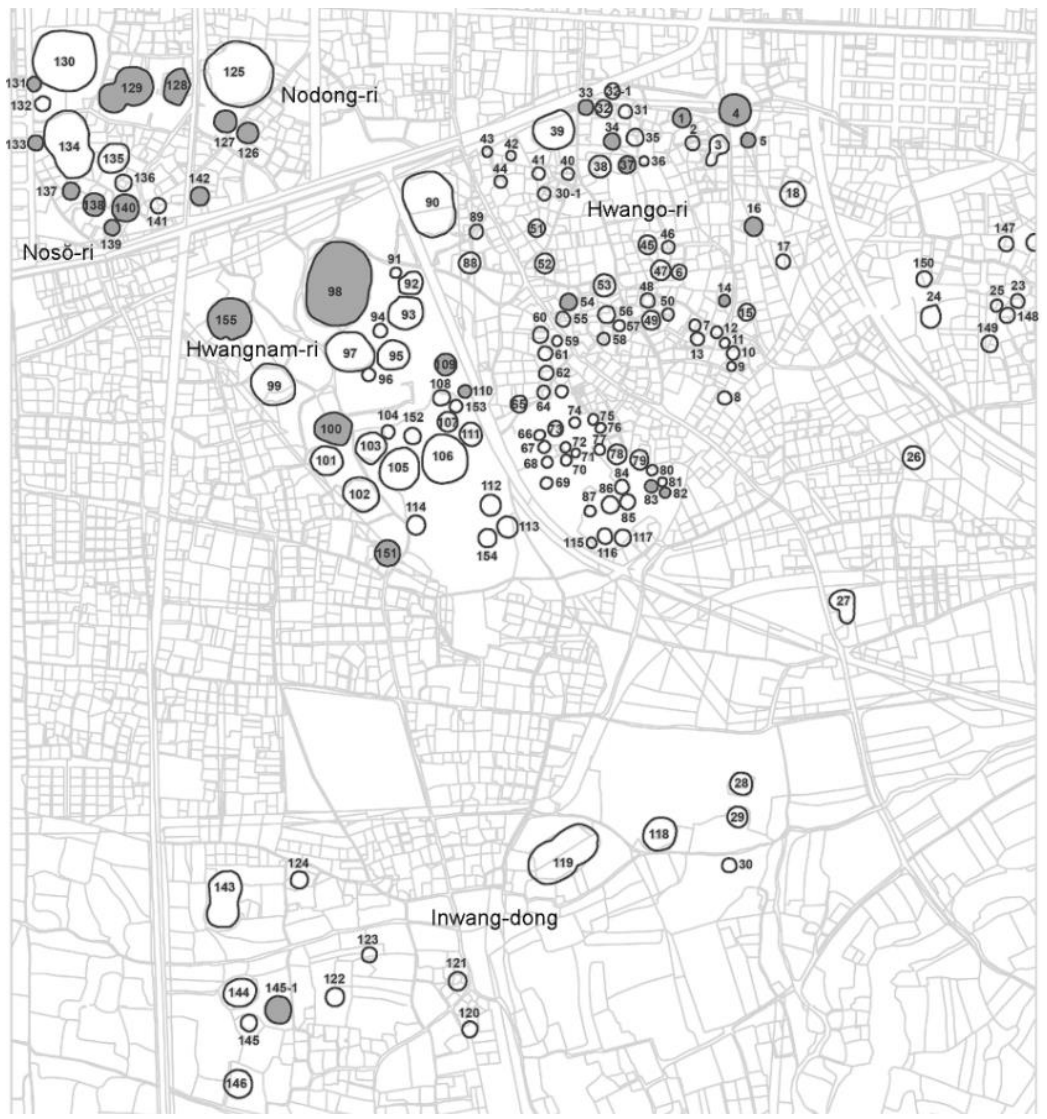

Fig. 1. Mounded graves in the cemetery North of Wŏlsŏng.

lem is that there are no indicators that would inform us of the identity of the graves' occupants. ${ }^{43}$ Most of the burials are not excavated and any ascription to a historically known individual must be purely speculative. The equipment with golden crowns, belts and other objects made of precious materials are considered to be indicative of the burial of a ruler.

43 Lee, “The Development of Royal Tombs," 103. 
These supposed "royal" regalia ${ }^{44}$ are, however, neither limited to only six burials nor to the biggest mounds. ${ }^{45}$ Moreover, the supposed linear development of the cemetery is not necessarily the most compelling interpretation of the observable distribution pattern. As can be seen in the case of the more intensively researched cluster of Nosŏ-ri/Nodong-ri, older wooden chamber graves with a stone mound and the younger stone chamber graves with an entrance appear next to each other. In other examples, multiple individuals occupied grave mounds and the formation of dense burial plots indicate the clusters were used for several generations. Therefore, a development of the cemetery from different nuclei which might have been established synchronously instead of diachronically is at least within the realms of possibility. ${ }^{46}$

Even though it seems obvious that the rulers were buried in the monumental mounds, it has been pointed out elsewhere that this interpretation is not as straightforward as it appears to be at first sight. There are arguments that the monumental mounds were constructed at the beginning of the Maripkan period and that later rulers were possibly interred in smaller, albeit still impressive mounds. ${ }^{47}$ A commonly accepted theory is that the cemetery north of Wŏlsŏng was exclusively used by the Kim clan, ${ }^{48}$ because all of the known Maripkans came, according to the historical sources, from this group. Considering the size of the burial ground and the fact that other clans such as the Park and Sŏk must have had a huge influence as well, it is not very plausible that only the members of one clan buried their dead in this cemetery.

44 Sarah M. Nelson, Gyeongju: The capital of golden Silla (London/New York: Routledge, 2017), 90.

45 Müller, "Monumental Burial Mounds," fig. 11.

46 A nuclei-based development has been recognized for other Silla cemeteries, see Lee Sungjoo and Sohn chul, "GISrŭl iyonghan silla kobun'gun kongganjojigŭi punsǒk," Han'gukkogohakpo 55 (April 2005): 77-103.

47 Müller, "Monumental Burial Mounds," 159.

48 Gina L. Barnes, State Formation in Korea: Historical and Archaeological Perspectives (Richmond: Curzon Press, 2001), 214-216. 
The complexity of the site is additionally demonstrated by the fact that the mounded graves do not represent the entirety of the burials in the cemetery. Excavations between the tumuli have revealed a huge number of contemporary burials that belong to different grave types encompassing smaller, levelled wooden chamber tombs with stone mounds, socalled stone-lined graves and pithos burials. ${ }^{49}$

\section{The Mounded Graves and Collective Memory}

This section explores how the mounded burials might have contributed to the creation, recalling, and alteration of the communicative and cultural memory within the Silla polity during the Maripkan period. It goes without saying that most if not all of the features related to the mortuary sphere serve several purposes simultaneously. The following discussion sheds light on the memorial aspect of the graves, and other factors that might have been of similar or higher importance are not mentioned here.

Perhaps a bit unsurprising is the insight that the construction of the graves as mounds, some of them reaching monumental measurements, is the most apparent attempt for creating a structure that has a long-lasting effect. Even if we assume that competition or simply the biography of the deceased played a role for the size of the mounds, there is no doubt that the constructors of the mounds were aware of the graves' impact on the perception of later generations. One of the purposes of a cemetery is remembrance or to be a link between the present and the past. The mounds in Kyŏngju were placed very prominently within the landscape. As is the case for other monumental structures, their key feature is visibility. ${ }^{50}$ The location in the plain and the space between the mounds imply that the funerals as well as most of the accompanying rituals were meant to be

49 See e.g. Yun, “The Distributional Patterns," 205-208.

50 Richard Huntington and Peter Metcalf, Celebrations of Death. The Anthropology of Mortuary Ritual (Cambridge: Cambridge University Press, 1979), 150. 
experienced by a larger audience. We may assume that the performance of rituals in different locations, the relations of the mounds to other built structures and to natural landmarks formed ultimately a mnemotope, a landscape charged with memories.

Irrespective of the chronological details of the cemetery's development, it is plausible to assume that in general the biggest mounds are the founder graves that established a new cluster. The significance of the older graves for the community is demonstrated by the multi-layered occupa-

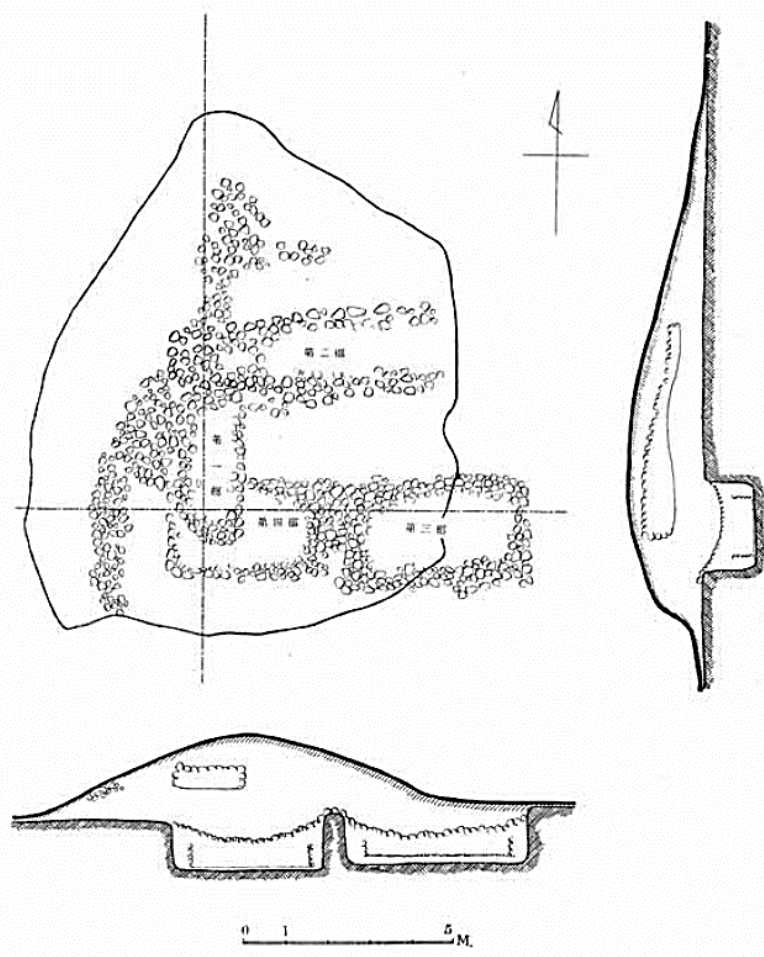

Fig. 2. Planum and profile of tumulus Hwangnam-dong 109. ${ }^{51}$

51 After GGMY, Sillagobun kich'ohaksuljosayŏn'gu III (Gyeongju: Kungnipkyŏngjumunhwajaeyŏn'guso, 2007), 215. 
tion history of burial complexes such as Hwango-ri 16 (fig. 3$)^{52}$ or by secondary occupations of mounded graves, as for instance observable in the case of the famous tumulus Hwangnam-dong 109 (fig. 2). Mound 100 in Hwangnam-dong has been linked, due to the disparity of its bigger size with the scantiness of the discovered grave goods, to a remark in the written sources that in the year 435 under Nulchi Maripkan older burials were renewed. ${ }^{53}$

According to an examination of Hyoun Cheol Shim, of 123 excavated and published graves in the cemetery north of Worlsŏng not less than 56 were part of a combined mound consisting of three or more burials, 28 were part of a burial plot consisting of multiple graves that might have been covered by a mound, and 10 were representatives of the iconic double mounds. ${ }^{54}$ The latter are considered to be the last resting places of married couples. Since it is unlikely that all single mounds belonged to unmarried individuals, there must have been additional criteria for the construction of a double mound.

The observable clustering of the tumuli has been plausibly interpreted as a means to signify the group affiliation of the buried individuals. ${ }^{55}$ Additionally, the spatial concentration of the mounds is clearly a reflection of a specific mode of memoria that establishes a connection to the previous burials. This stands in contrast to later royal burials, which often appear as single mounds in closer or wider distance from Kyŏngju. ${ }^{56}$ Here only the individual ruler was honored and commemorated. Based on this observation we might formulate the hypothesis that during the Mar-

52 Hwango-ri 16 is an exception from the presupposed norm that the biggest mound stood at the beginning of a cluster's development, since in this case the later mound A was bigger than the older mounds (fig. 3).

53 Kim Changho, 'Kyŏngju Hwangnamdong 100hobun(Kŏmch'ong)ŭi chaegŏmt'o, “Han'guksanggosahakpo 8 (December 1991), 85-88.

54 Shim Hyeonchol, "Silla chŏksŏngmokkwangmyoŭi kujowa ch'ukchogongjŏng, “Han'gukkogohakpo 88 (September 2013): 85-86.

55 Lee, "The Development of Royal Tombs," 92-100.

56 Lee, "The Development of Royal Tombs," 102-115. 
ipkan period, bigger mounds accompanied by a number of satellite burials represent a successful attempt to establish a powerful narrative about the individual in the founder grave. Bigger tumuli such as mound 119 or 143, which stand more or less isolated, might be examples of failed attempts (fig. 1).

It is particularly noteworthy that burial plots formed differently over time, which in all likelihood represents divergent commemorative practices. For instance, the mounds in the cluster of Nosŏ-ri/Nodong-ri are individually distinguishable (fig. 1), whilst the dense plot of Hwango-ri 16 , which includes at least 10 inhumation graves and one cremation burial,

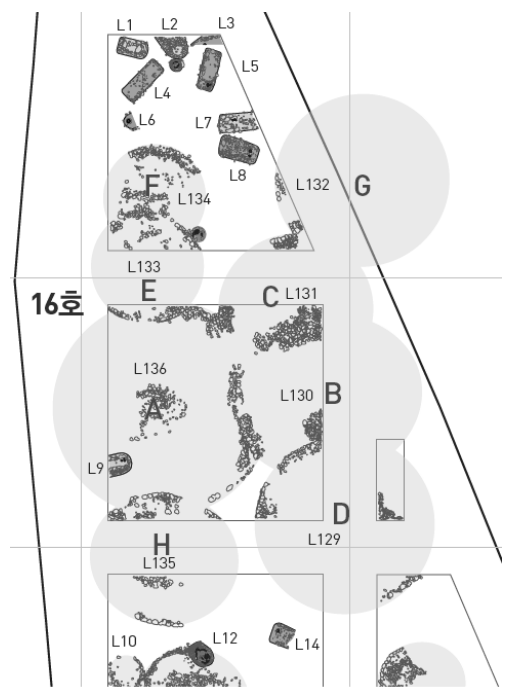

(A)
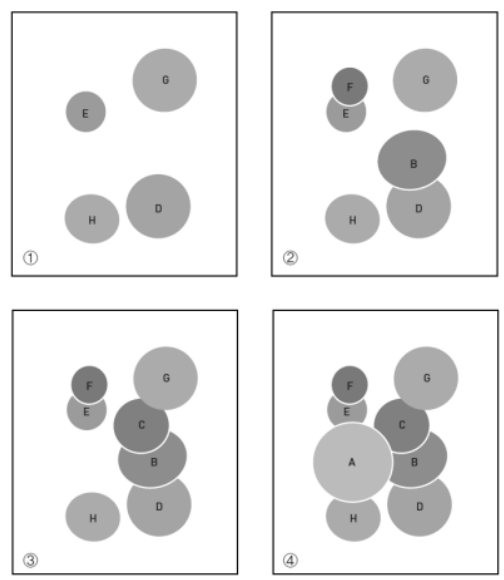

(B)

Fig. 3. Planum of the mound complex Hwango-ri 16 (A) and its chronological development (B). ${ }^{57}$

57 Ch'oe Sŏngu, "1. H·Lchigu nae kijosagobun kŏmt'o -Hwangori16hobunŭl chungsimŭro-," in Kyŏngju tchoksaemjigu sillagobunyujökVIII- H·Lchigu punp'ojosa pogosŏ, ed. Kungnipkyŏngjumunhwajaeyŏn'guso (Kyŏngju: Kungnipkyŏngjumunhwajaeyŏn'guso, 2017), fig. 4; 5. 
is an accumulation of eight mounds that were merged to such a degree that the distinction of single graves might have become impossible (fig. 3 ). In the former case, a commemorative ceremony for a particular individual could focus on a specific mound which required detailed knowledge of the identity of the interred individual. The seeming absence of identifying markers rendered it necessary that this information was added to the collective long-term memory. The increasing number of clearly distinguishable graves was in this regard proof of lineage for the descendants of the deceased. In the case of Hwango-ri 16, however, the lack of visual and spatial distinction of the merged mounds was probably a less efficient way to demonstrate the origin and history of the burying group.

Although difficult to prove, it is plausible that the mounds were places for commemorative rituals after the funeral. Recent discoveries of pottery vessels containing remnants of food and smaller vessels at the foot of mound 129, also known as Sŏbong'chong, may be proof for this assumption. ${ }^{58}$ The remains of an offering table in front of the same grave might be an indicator of seasonal ritual performances dedicated to the individual grave occupant. ${ }^{59}$ For Nosŏ-ri/Nodong-ri, the later addition of mounded stone chamber tombs such as Mach'ong and Ssangsangch'ong ${ }^{60}$ to the cluster is evidence that the burials of the Maripkan period were part of the cultural memory in the early Unified Silla period.

The construction of the wooden burial chambers and of the stone mounds was highly determined by the final size of the tumuli and particular differences might be explained with chronological changes or grouprelated traditions. The latter could be traced to cultural memory, but this

58 Press Release, "Yŏksagiroge ŏptŏn sillaŭi tokt'ŭkhan chesa ŭmsigi hwagindoeda!" Kungnip Chung'ang Pangmulgwan 2020-55 (2020): 1-6, accessed November 20, 2020, https://www.museum.go.kr/site/main/archive/post/article_17062.

59 Kim Taeshik, "Excavation of Seobongchong Tomb," HistoryLibrary, accessed September 7, 2020, https://historylibrary.net/entry/\%EC\%84\%9C\%ЕB\%B4\%8

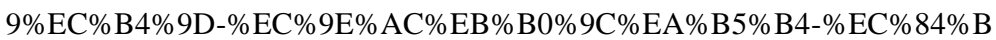
$1 \% \mathrm{EA} \% \mathrm{~B} 3 \% \mathrm{BC}-\% \mathrm{EC} \% \mathrm{~A} 0 \% 95 \% \mathrm{~EB} \% \mathrm{~A} 6 \% \mathrm{AC}$.

60 GGMY, Sillagobun, 237-239; 244-245. 
is at the current state of research impossible to prove. The furnishing of the graves was part of the burial customs and thus a highly ritualized process. It has to be assumed that the combination and placement of the grave goods within the grave chamber is the result of conscious decisions which were founded in the cultural memory. Patterns and possible alterations of the equipment may provide indications for concurring or changing narratives in the cultural memory. In order to trace these differences a minute examination of each burial would be necessary, which is beyond the scope of the present article. Therefore, only a few basic observations may be mentioned.

The grave goods can be roughly divided into three bigger groups: the personal adornment plus weapons and tools placed next to the body, smaller deposits of vessels and other artefacts in the chamber, and objects that were densely stored at the head or foot end of the chamber in a compartment or box. ${ }^{61}$ The latter objects were seemingly used for ritual activities outside the grave since they were not arranged for display inside the chamber. Regular combinations and specific patterns of the grave goods have been recognized and they are commonly related to status or gender. ${ }^{62}$ Although there is no doubt that these factors played a role, they do not explain the over-furnishing and conspicuous consumption that can be observed in some of the mounds. In particular, the lavishly equipped graves alter the cultural text of the funerals by replacing commonly used elements with exotic and more prestigious objects. The ostentatious disposal of large amounts of objects and highly valued goods is a behavioral pattern intended to create a memorable event. The inclusion of foreign

61 Choi Suhyoung, "Kyŏngjujiyŏk chŏksŏngmokkwangmyoŭi wigyegujo kŏmt'o," Chunganggogoyŏn'gu 12 (2013): 73-75; fig. 3.

62 Choi, "Kyŏngjujiyŏk," 87-90. Choi Byounghyun, "Silla chŏn'gi kyŏngju wŏlsŏngbukkobun'gunŭi kyech'ŭngsŏnggwa poksikkun," Han'gukkogohakpo 104 (September 2017): 78-123. Richard Pearson et al., "Social Ranking in the Kingdom of Old Silla, Korea: Analysis of Burials," Journal of Anthropological Archaeology 8, no.1 (March 1989): 1-50. 
goods might be related to notions of esoteric knowledge and magic. ${ }^{63}$

In some cases, the objects could have been famous artefacts whose possession was linked to high prestige and which were part of the cultural memory as in mythological narratives. The interment of a famous object would have been another strong mnemonic element added to the grave. Although the relevance of a specific artefact for the cultural memory of the community is hard to ascertain, there is evidence that objects were used as mnemonic devices. Among the exceptional finds in mound 140 at Nosŏ-ri, also known as Houch'ong, a bronze lidded bowl was discovered among the grave goods stored in the eastern end of the grave chamber. ${ }^{64}$ An inscription molded to the bottom of the vessel states that this is the tenth bowl made in 415 for celebrating the famous King Kwanggaet'o of Koguryŏ (fig. 4), who died in 413. Mound 140 is commonly dated to the second quarter of the $6^{\text {th }}$ century, ${ }^{65}$ which means that the bowl was in circulation for one hundred years. The commemorative character of the vessel is without doubt and we may assume that particularly special and prestigious objects were charged with meaning and narratives. Other examples of outstanding objects, whose mnemonic function is more explicit through the addition of inscriptions, are the famous golden belt from Hwangnamdaech'ong north which carries the inscription "belt for the wife/queen" 66 or the sword in mound 128 at Nosŏ-ri, known as Kŭmgwanch'ong, which carried the inscription "Yisajiwang."

63 Mary W. Helms, Ulysses' Sail. An Ethnographic Odyssey of Power, Knowledge, and Geographical Distance (Princeton: Princeton University Press, 1988), 74; 94; 166.

64 GGMY, Sillagobun, 232 fig. 1.

65 See e.g. Choi, "Kyŏngjujiyŏk," 72.

66 Ham Sonseop, "Gold Crown and Gold Belt from the North Mound of Hwangnamdaechong Tomb," National Museum of Korea, accessed November 20, 2020, https://www.museum.go.kr/site/eng/archive/united/14942.

67 Lee Yonghyeon, "Munja charyoro pon kŭmgwanch'ong ch'ult'o taedo myŏngmunŭi 'isajiwang,", Sillasahakhoe 32 (2014): 81-83. See this article also for more inscriptions on objects found in mounded graves in Kyŏngju. 

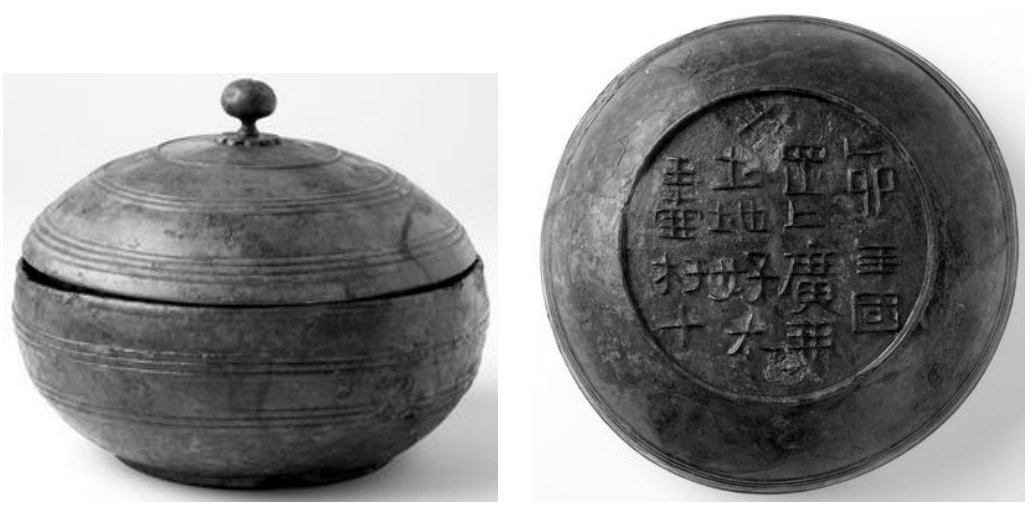

Fig. 4. Bronze Lidded Bowl with Inscription of Hou. ${ }^{68}$

If the ritual disposal of prestigious objects should have had any effect on the communicative and potential cultural memory of the community, the grave goods, no matter to which category they actually belonged to, had to be presented to the public. Although there are no historical accounts of the process of Silla funerals, a few occasions for the display of the objects to a wider audience are obvious. First, it is assumable that the deceased was laid in state, which offered a possibility to display valuable objects together with the body. The choice of the right burial place, the activation of the necessary labor force, the retrieval of the needed resources, and the actual construction work required some time. ${ }^{69}$ Other possible arrangements such as the choice of the right day for particular rituals might have increased the time between death and interment as well.

The procession from the place where the body was kept to the burial site was another important opportunity for demonstrating the material

68 "Bronze Lidded Bowl with Inscription of Hou (壼杅)," National Museum of Korea, accessed November 20, 2020, https://www.museum.go.kr/site/eng/relic/r epresent/view?relicId=1917\#.

69 Matthew Conte and Jangsuk Kim, "An economy of human sacrifice: The practice of sunjang in an ancient state of Korea," Journal of Anthropological Archaeology 44 (December 2016): 21. 
power of the deceased's group. The following ceremonies that took place at the grave were probably the most effective and powerful events in relation to communicative memory. Recent follow-up excavations of Kŭmgwanch'ong have led to the insight that the stone mound, which was shaped in graves of big or monumental measurements like a truncated pyramid, ${ }^{70}$ was constructed before the wooden grave chamber. Dae-hwan Kim has argued that this stone platform was used as a stage for the performance of mortuary rituals. ${ }^{71}$ The elevated position of the platform would have allowed for a larger audience to witness these rituals.

Another aspect of the funerary ritual that is ascertainable in some of the mounded graves is the interment of human sacrifices. Evidence for the performance of this ritual is, for instance, known from Hwangnamdong 109 north, Hwangnamdaech'ong south, Kŭmgwanch'ong and Hwango-ri $14 .^{72}$ The existence of the custom to sacrifice humans is proven by its prohibition under Chiljŭng Maripkan in the year 502. ${ }^{73}$ Matthew Conte and Jangsuk Kim have offered some insights on the enormous economic investment of this kind of ritual. The sacrificed individuals were apparently members of the community and in all likelihood from the upper stratum of the society. ${ }^{74}$ Besides all the ideological and power-related implications, it is assumable that this extended death, perhaps even publicly performed, was an extremely emotional and memorable moment that became part of the communicative memory. Perhaps the justification for performing human sacrifices was linked to the existence or creation of narratives embedded in the cultural memory.

Another central element of funeral rituals that can be cross-culturally observed are feasts. Conte and Kim have suggested that the pottery ves-

70 Shim, "Silla chŏksŏngmokkwangmyoŭi," fig. 12.

71 Kim Daehwan, "Chisangjŏksŏksik chŏksŏngmokkwangmyoŭi mokkwakpuwa chŏksŏkpuŭi sŏnggyŏk," Kogohakchi 22 (2016): 103; 105.

72 Lee Sungjoon and Kim Suwhan, "Human Sacrificial Burial in ancient Korean Society.” Han'gukkogohakpo 81 (December 2011): fig. 6.

73 Conte and Kim, "An economy," 15.

74 Conte and Kim, "An economy," 18. 
sels in the graves and their content, consisting of the remains of animals and plants, may be indicators of feasting activities during the course of the funeral. ${ }^{75}$ Although it would require a deeper analysis to ascertain whether the stored vessels were indeed used in this way, the consumption of food and beverages was in all likelihood a central part of the funerary customs. Conte and Kim have described with reference to the work of Brian Hayden ${ }^{76}$ the beneficial factors that were connected to the hosting of feasts such as the display of power, the confirmation of authority, the establishment of obligations between the guests and the host, etc. ${ }^{77}$ Hayden has also emphasized the physical reactions to feasts, stimulated through the types of served food and the accompanying elements such as scents, music, the choice of colors for the garment, dances, sacrifices, and intoxication. ${ }^{78}$ As Yannis Hamilakis has pointed out, the ingestion of food and beverages during rituals becomes a literal embodiment of the ritual practice $^{79}$ and thus, we may add, of the cultural memory. However, the provision of food increases the compliance of the feast's participants ${ }^{80}$ and in connection with the emotional state and the extraordinary setting of the entire funerary rituals the participants might become more receptive to subtle changes of the cultural memory.

\section{Conclusion}

Collective memory with its two key elements, the communicative and cultural memory, is of crucial importance for the formation and cohesion

75 Conte and Kim, “An economy,” 18.

76 Brian Hayden, The Power of Feasts. From Prehistory to the Present (Cambridge: Cambridge University Press, 2014).

77 Conte and Kim, “An economy," 21.

78 Hayden, The Power, 12-14.

79 Yannis Hamilakis, Archaeology of the Senses. Human Experience, Memory, and Affect (New York: Cambridge University Press, 2013), 81.

80 Hayden, The Power, 20-21. 
of a society. Particularly, cultural memory takes a significant role in this regard since it transmits the knowledge of the core events and narratives over a long period of time. Rites and festivals, the two modes of recalling cultural memory, are only indirectly represented in the archaeological record. Through general considerations of the funerary process it is, however, possible to attain a basic understanding of how the funeral ceremony in Silla's Maripkan period with all the accompanying activities and events such as the construction of the mound, the ostentation, human sacrifices and feasts might have influenced communicative memory. Nevertheless, it remains difficult to ascertain which of these memorable elements, if any, translated into the collective long-term memory.

The most obvious connection to cultural memory is established by the clusters of mounded graves which provided through their presence and visibility an anchor in time and space. Even after the memory of the actual funeral was lost, the continued existence of the mounds required an explanation. They were the visual proof of a lineage that went back to influential individuals and groups of older times. In this sense the mounds served a similar function as a genealogical table or chronicle in later times. Groups who constructed individual mounds instead of expanding already existing tumuli had to invest more resources, but eventually gained a stronger base for their claims to power and authority. The absence of markers providing information about the identity of the interred individual inevitably required a reference to cultural memory in order to preserve the information beyond the 'floating gap.' The construction of the mounds with all the accompanying rituals and festivities had an immediate effect on communicative memory, whilst their size and placement had a stronger relevance for the collective long-term memory. They ultimately formed together with the rivers, mountains, forests and built structures the mnemotope of Silla's cultural memory.

Irrespective of the question, of whether only members of the Kim clan or other family groups were buried in the cemetery north of Wolsong, it becomes once more apparent that the burial site was not a place where people were uniformly buried according to their social status and other 
roles. The cemetery was an arena of competition in which different groups struggled for power and promoted their version of cultural memory. Perhaps a weak reflection of competing narratives might be the fact that in epigraphic texts of late Silla members of the Kim clan trace their origin either to the famous progenitor Kim Alchi or to Sŏnghan, which is probably another name for Alchi's son Sehan. ${ }^{81}$

The proof of lineage, which is a crucial element for justifying any claim of authority in aristocratic societies, became visible and therefore believable through the existence of the mounds. We may argue the construction of the tumuli was a necessary prerequisite to complete the process of Silla's state formation.

\section{References}

1. Assmann, Jan. "Kollektives Gedächtnis und kulturelle Identität." In Kultur und Gedächtnis, edited by Jan Assmann and Tonio Hölscher: 9-19. Frankfurt a. M.: Suhrkamp, 1988.

2. Assmann, Jan. "Das Kulturelle Gedächtnis." In Kolloquien des MaxWeber-Kollegs XV-XXIII, edited by Wolfgang Schluchter: 9-27. Erfurt: Max-Weber-Kolleg, 2001.

3. Assmann, Jan. Cultural Memory and Early Civilization, Writing, Remembrance and Political Imagination. Cambridge: Cambridge University Press, 2011.

4. Barnes, Gina L. "The Emergence and Expansion of Silla from an Archaeological Perspective." Korean Studies 28 (2004): 14-48.

5. Barnes, Gina L. State Formation in Korea: Historical and Archaeological Perspectives. Richmond: Curzon Press, 2001.

6. Best, Jonathan W. A History of the Early Korean Kingdom of Paek-

81 Jeon DoegJae, "The Constitution of the Ruling Elite in Middle and Late Silla," in State and Society in Middle and Late Silla, ed. Richard D. McBride II (Cambridge, MA: Korea Institute, Harvard University, 2010), 33-37. 
che. Cambridge, MA: Harvard University Press, 2006.

7. Brather, Sebastian. Ethnische Interpretationen in der frühgeschichtlichen Archäologie. Geschichte, Grundlagen und Alternativen. Berlin/New York: Walter de Gruyter, 2004.

8. Byington, Mark E. "Some Problems with Early Koguryŏ-Silla Relations Described in the Samguk sagi." Seoul Journal of Korean Studies 29, no. 1 (June 2016): 115-132.

9. Ch'oe, Sŏngu. "1. H·Lchigu nae kijosagobun kŏmt'o Hwangori16hobunŭl chungsimŭro-." In Kyŏngju tchoksaemjigu sillagobunyujŏkVIII- H·Lchigu punp'ojosa pogosŏ, edited by Kungnipkyŏngjumunhwajaeyŏn'guso, 398-405. Kyŏngju: Kungnipkyŏngjumunhwajaeyŏn'guso, 2017.

10. Choi, Byounghyun. "Silla chŏn'gi kyŏngju wŏlsŏngbukkobun'gunŭi kyech'ŭngsŏnggwa poksikkun.” Han'gukkogohakpo 104 (September 2017): 78-123.

11. Choi, Sughyoung. "Kyŏngjujiyŏk chŏksŏngmokkwangmyoŭi wigyegujo kŏmt'o." Chunganggogoyŏn'gu 12 (2013): 62-94.

12. Connerton, Paul. How Societies Remember. Cambridge: Cambridge University Press, 1989.

13. Conte, Matthew and Jangsuk Kim. "An economy of human sacrifice: The practice of sunjang in an ancient state of Korea." Journal of Anthropological Archaeology 44 (December 2016): 14-30.

14. Davey, Jack. "Unreliable Narratives: Historical and Archaeological Approaches to Early Silla." Seoul Journal of Korean Studies 29, no. 1 (June 2016): 7-32.

15. DeBoeck, Filip. "Bodies of Remembrance: Knowledge, Experience and the Growing of Memory in Luunda Ritual Performance." In Rites et Ritualization, edited by Georges Thinès and Luc de Heusch: 113138. Paris and Lyon: Librairie Philosophique J. Vrin, 1995.

16. GGMY. Sillagobun kich'ohaksuljosayŏn'gu III. Gyeongju: Kungnipkyŏngjumunhwajaeyŏn'guso, 2007.

17. Graf, Klaus. "Ursprung und Herkommen. Funktionen vormoderner Gründungserzählungen." In Geschichtsbilder und Gründungsmythen, 
edited by Hans-Joachim Gehrke: 23-36. Würzburg: Ergon-Verlag, 2001.

18. Halbwachs, Maurice. The Collective Memory. New York: Harper and Row Publishers, 1980.

19. Ham, Sonseop. "Gold Crown and Gold Belt from the North Mound of Hwangnamdaechong Tomb." National Museum of Korea. Accessed November 20, 2020. https://www.museum.go.kr/site/eng/arch ive/united/14942.

20. Hamilakis, Yannis. Archaeology of the Senses. Human Experience, Memory, and Affect. New York: Cambridge University Press, 2013.

21. Hayden, Brian. The Power of Feasts. From Prehistory to the Present. Cambridge: Cambridge University Press, 2014.

22. Helms, Mary W. Ulysses' Sail. An Ethnographic Odyssey of Power, Knowledge, and Geographical Distance. Princeton: Princeton University Press, 1988.

23. Huntington, Richard and Peter Metcalf. Celebrations of Death. The Anthropology of Mortuary Ritual. Cambridge: Cambridge University Press, 1979.

24. Jeon, Deogjae. "The Constitution of the Ruling Elite in Middle and Late Silla." In State and Society in Middle and Late Silla, edited by Richard D. McBride II, 21-56. Cambridge, MA: Korea Institute, Harvard University, 2010.

25. Kim, Changho. "Kyŏngju Hwangnamdong 100hobun(Kŏmch'ong)ŭi chaegŏmt'o." Han'guksanggosahakpo 8 (December 1991): 79-92.

26. Kim, Daehwan. "Chisangjŏksŏksik chŏksŏngmokkwangmyoŭi mokkwakpuwa chŏksŏkpuŭi sŏnggyŏk.” Kogohakchi 22 (2016): 89114.

27. Kim, Taeshik. "Excavation of Seobongchong Tomb." HistoryLibrary, September 7, 2020. https://historylibrary.net/entry/\%EC\%84\%9C\%E В\%B4\%89\%ЕC\%B4\%9D-\%ЕC\%9Е\% АC\%ЕВ\%B0\%9C\%ЕA\%B5 $\%$ B $4-\%$ EC $\% 4 \%$ B1\%ЕA\%B3\%BC-\%ЕC\%A0\%95\%ЕB\%A6\%AC.

28. Lee, Sungjoo and Sohn Chul. "GISrŭl iyonghan silla kobun'gun kongganjojigŭi punsŏk.” Han'gukkogohakpo 55 (April 2005): 77-103. 
29. Lee, Sungjoon and Suwhan Kim. "Human Sacrificial Burial in ancient Korean Society." Han'gukkogohakpo 81 (December 2011): 109138. [in Korean]

30. Lee, Yonghyeon. 'Munja charyoro pon kŭmgwanch'ong ch'ult'o taedo myŏngmunŭi “isajiwang."” Sillasahakhoe 32 (2014): 433-450.

31. McBride II, Richard D. "Introduction." In State and Society in Middle and Late Silla, edited by Richard D. McBride II, 3-20. Cambridge, MA: Korea Institute, Harvard University, 2010.

32. Müller, Sebastian. "Monumental Burial Mounds in Kyŏngju: Remarks on their Socio-political Meaning." International Journal of Korean History 24, no. 2 (2019): 133-169.

33. National Museum of Korea. "Bronze Lidded Bowl with Inscription of Hou (壼杆).” Accessed November 20, 2020. https://www.museum.g o.kr/site/eng/relic/represent/view?relicId=1917\#

34. Nelson, Sarah M. Gyeongju: The capital of golden Silla. London/New York: Routledge, 2017.

35. Olsen, Bjørna. In Defense of Things. Archaeology and the Ontology of Objects. Lanham: Altamira Press, 2010.

36. Pearson, Richard, Jon-wook Lee, Wonyoung Koh, and Anne Underhill. "Social Ranking in the Kingdom of Old Silla, Korea: Analysis of Burials." Journal of Anthropological Archaeology 8, no.1 (1989): 1-50.

37. Press Release. "Yŏksagiroge ŏptŏn sillaŭi tokt'ŭkhan chesa ŭmsigi hwagindoeda!" Kungnip Chung'ang Pangmulgwan 2020-55, (2020): 1-6. Accessed November 20, 2020. https://www.museum.go.kr/site/m ain/archive/post/article_17062.

38. Schustereder, Stefan J. Strategies of Identity Construction. The Writings of Gildas, Aneirin and Bede. Göttingen: Bonn University Press, 2015.

39. Schwedler, Gerald, Ruth Schilling, Sebastian Kolditz. "D. Gedächtnis, Gedenken und Herrschaft in transkultureller Perspektive." In Monarchische Herrschaftsformen der Vormoderne in transkultureller Perspektive, edited by Wolfram Drews, Antje Flüchter et al., 239-344. 
Berlin/Munich/Boston: De Gruyter, 2015.

40. Shim, Hyoencheol. "Silla chŏksŏngmokkwangmyoŭi kujowa ch'ukchogongjŏng.” Han'gukkogohakpo 88 (September 2013): 72-119.

41. Shim, Hyeoncheol. "Kyŏngjubunjiŭi kojihyŏnggwa taerŭngwŏn irwŏnsillagobunŭi ipchi.” Munhwajae 51, no. 4 (December 2018): 234253.

42. Veit, Ulrich. "Kulturelles Gedächtnis und materielle Kultur in schriftlosen Gesellschaften: Anthropologische Grundlagen und Perspektiven für die Urgeschichtsforschung." In Die Dinge als Zeichen. Kulturelles Wissen und materielle Kultur, edited by Tobias L. Kienlin, 23-40. Bonn: Rudolf Habelt, 2005.

43. Wertsch, James V. 2009. "Collective Memory." In Memory in Mind and Culture, edited by Pascal Boyer and James V. Wertsch, 117-137. Cambridge: Cambridge University Press.

44. Yun, Hyoungjun, "The Distributional Patterns of Silla Burial Grounds and the Character of Outer Coffin Tombs in Jjoksaem Site, Gyeongju." Munhwajae 50, no. 4 (December 2017): 198-221. [in Korean] 
$<$ Abstract $>$

\section{Mounded Mnemonics: Tumuli and Collective Memory in Old Silla}

The present article discusses the mounded tombs of the Maripkan period (356-514) located in the city of Kyŏngju in the southeastern part of the Korean Peninsula regarding their impact on the collective memory of the early Silla polity. The theoretical framework for the following considerations draws from the seminal research of the cultural scientist Jan Assmann, who distinguishes between a communicative and cultural memory. It is being argued that one of the motivations for constructing the monumental and lavishly equipped graves was the manipulation of communicative memory by creating memorable events in the course of the funerary process. The construction of the graves as mounds created spatial reference points in the landscape which affected subsequently the collective long-term or cultural memory. Consequently, it is assumed that the mounds became mnemonic devices for cultural memory and, therefore, crucial factors for the formation and stabilization of the kingdom.

Keywords: Silla, Kyŏngju, mounded tombs, collective memory, elite culture 
〈국문초록〉

\section{분구 기호: 고(古) 신라의 분구묘와 문화적 기억}

Sebastian Müller (부산외국어대학교 지중해연구소)

본고는 한반도 남동부 지역 경주에 위치한 마립간 시대(356-514년)의 고분이 고신라 정권의 집단 기억에 미치는 영향에 대하여 논의한다. 독일의 문화학자 얀 야스만의 의 사 소통과 문화적 기억을 구별하는 연구를 토대로 삼아 본고의 이론적 틀을 세웠다. 장례식 과정에서 기억에 남을 수 있는 사건들을 만듬으로써 의사소통의 기억을 조작하 는데 이는 기념비적이며 화려한 무덤을 짓게한 동기 중 하나라고 주장하는 바이다. 고 분 형태의 무덤을 지으면 공간적 기준점이 생겨나 훗날 집단적이며 장기적인 혹은 문화 적 기억에 영향을 끼친다. 결과적으로 고분의 건설은 문화적 기억을 위한 연상 기호적 장치가 되었고, 그러므로 국가의 형성과 안정화에 주요한 요소라고 가정할 수 있다.

주제어: 신라, 경주, 고분, 집단 기억, 지배층 문화 
